\title{
Family Caregiver Access of Online Medical Records: Findings from the Health Information National Trends Survey
}

J Gen Intern Med 36(10):3267-9

DOI: $10.1007 / \mathrm{s} 11606-020-06350-8$

(c) Society of General Internal Medicine 2020

\section{INTRODUCTION}

Over 40 million Americans provide unpaid support to an adult relative for tasks including accompanying them to doctor visits and/or supporting them in medical decisions. ${ }^{1}$ Over the past several years-and particularly amid COVID-19-there has been increasing interest and demand for caregivers to be more involved in communication with providers to support patient engagement and patient-centered care as evidenced by recent state and federal policy initiatives to expand support to caregivers. ${ }^{2,3}$ One way to improve communication between caregivers and providers is through an online medical record (patient portal), which enables patients to acquire important health information and communicate with medical providers. ${ }^{4}$ However, caregivers' access to adult care recipients' portals is limited and varies across healthcare organizations and states. ${ }^{2}$ The objective of this study was to determine the relationship between socio-demographic attributes and responsibilities of caregivers and likelihood of (a) communicating with recipients' providers and (b) accessing recipients' online records.

\section{METHODS}

We performed a secondary analysis of data from the National Cancer Institute's nationally representative 2018 Health Information National Trends Survey (HINTS) 5 Cycle 2, administered to 3504 US adults between January and May 2018. Our final analytic sample included 191 self-identified family caregivers of adults supporting the following: (a) a spouse/partner $(n=51)$, (b) a parent/parents $(n=101)$, or (c) another family member $(n=39)$.

Received June 30, 2020

Revised August 11, 2020

Accepted November 16, 2020

Published online December2, 2020
We first examined socio-demographic attributes and responsibilities of caregivers. We estimated multivariable logistic regression models to investigate relationships between care recipient type and (1) responsibility for communicating with providers and (2) accessing care recipient's online medical records. Models adjusted for age, race/ethnicity, sex, education, activities of daily living support, cognitive condition support, proximity to care recipient, and hours spent caregiving.

\section{RESULTS}

The majority of family caregivers of adults (74-89\%) report responsibility for communicating with care recipients' healthcare providers (Table 1). However, only 11$27 \%$ of caregivers accessed their care recipients' online medical record in the previous 12 months, with caregivers of spouses most likely to access care recipient's online record. In multivariable analysis (Table 2), caregivers of a parent were significantly less likely than caregivers of spouses to report being responsible for communicating with providers $(\mathrm{OR}=4.34, p=0.003$ ). Similarly, caregivers supporting a parent were significantly less likely than those supporting a spouse/partner to report using the online medical record $(\mathrm{OR}=0.28, p$ $=0.01)$.

\section{DISCUSSION}

Most family caregivers are responsible for communicating with healthcare providers for their adult care recipients. Few family caregivers, however, are accessing the online medical records of their care recipients. Family caregivers of parents and other adult family relatives are less likely than caregivers of a spouse/partner to access their recipient's online medical records.

Access to information about care recipient's diagnoses, test results, and prognosis can enable caregivers to give providers helpful contextualizing details about care recipients' symptoms or behaviors, to advocate for their relative's needs and preferences, and to provide effective support. ${ }^{5}$ Public health disasters like the COVID-19 
Table 1 Types and characteristics of caregivers and caregiving $(n=191)$

\begin{tabular}{|c|c|c|c|c|c|}
\hline & $\begin{array}{l}\text { Spouse } \\
n=51 \\
\%\end{array}$ & $\begin{array}{l}\text { Parent } \\
n=101 \\
\%\end{array}$ & $\begin{array}{l}\text { Another family } \\
\text { member } \\
n=39 \\
\%\end{array}$ & $\begin{array}{l}\text { Test statistic and } p \\
\text { value }\end{array}$ & $\begin{array}{l}\text { Test } \\
\text { performed }\end{array}$ \\
\hline \multicolumn{6}{|l|}{ Demographic characteristics } \\
\hline $\begin{array}{l}\text { Age } \\
\text { Mean (s.d.) }\end{array}$ & $\begin{array}{l}66.33 \\
(14.19)\end{array}$ & $\begin{array}{l}56.04 \\
(11.59)\end{array}$ & $55.87(14.93)$ & $11.76(p<0.001)$ & ANOVA \\
\hline Gender & & & & & Pearson's \\
\hline $\begin{array}{l}\text { Female } \\
\text { Male }\end{array}$ & $\begin{array}{l}58.82 \\
41.18\end{array}$ & $\begin{array}{l}67.33 \\
32.67\end{array}$ & $\begin{array}{l}71.79 \\
28.21\end{array}$ & $1.82(p=0.40)$ & Chi-squared \\
\hline \multicolumn{6}{|l|}{ Education } \\
\hline $\begin{array}{l}\text { Less than high school } \\
\text { High school equivalent } \\
\text { Some college } \\
\text { BA or higher }\end{array}$ & $\begin{array}{l}1.96 \\
15.69 \\
33.33 \\
49.02\end{array}$ & $\begin{array}{l}0.00 \\
8.91 \\
34.65 \\
56.44\end{array}$ & $\begin{array}{l}2.56 \\
10.26 \\
38.46 \\
48.72\end{array}$ & $4.45(p=0.616)$ & $\begin{array}{l}\text { Pearson's } \\
\text { Chi-squared }\end{array}$ \\
\hline Race/ethnicity & & & & & Pearson's \\
\hline $\begin{array}{l}\text { White, non-Hispanic } \\
\text { Not White and/or Hispanic }\end{array}$ & $\begin{array}{l}70.59 \\
29.41\end{array}$ & $\begin{array}{l}65.35 \\
34.65\end{array}$ & $\begin{array}{l}64.10 \\
35.90\end{array}$ & $0.54(p=0.762)$ & Chi-squared \\
\hline Employment & & & & & Pearson's \\
\hline $\begin{array}{l}\text { Employed } \\
\text { Not employed }\end{array}$ & $\begin{array}{l}35.29 \\
64.71\end{array}$ & $\begin{array}{l}53.47 \\
46.53\end{array}$ & $\begin{array}{l}48.72 \\
51.28\end{array}$ & $4.51(p=0.105)$ & Chi-squared \\
\hline \multicolumn{6}{|l|}{ Location and duration of caregiving } \\
\hline $\begin{array}{l}\text { Duration of caregiving } \\
\text { Less than or equal to } 5 \text { years } \\
\text { More than } 5 \text { years }\end{array}$ & $\begin{array}{l}60.78 \\
39.22\end{array}$ & $\begin{array}{l}73.27 \\
26.73\end{array}$ & $\begin{array}{l}56.41 \\
43.59\end{array}$ & $4.61(p=0.100)$ & \\
\hline $\begin{array}{l}\text { Proximity to care recipient } \\
\text { Lives in the same household } \\
\text { Within } 1 \mathrm{~h} \\
\text { More than } 1 \mathrm{~h}\end{array}$ & $\begin{array}{l}92.16 \\
7.84 \\
0\end{array}$ & $\begin{array}{l}24.75 \\
56.44 \\
18.81\end{array}$ & $\begin{array}{l}43.59 \\
41.03 \\
15.38\end{array}$ & $62.35(p<0.001)$ & $\begin{array}{l}\text { Fisher's exact } \\
\text { test }\end{array}$ \\
\hline Hours per week (mean [s.d.]) & $\begin{array}{l}46.06 \\
(51.14)\end{array}$ & $\begin{array}{l}20.59 \\
(35.36)\end{array}$ & $24.21(35.57)$ & $7.03(p=0.001)$ & ANOVA \\
\hline $\begin{array}{l}\text { Health conditions of care recipients } \\
\text { Supports physical condition }\end{array}$ & 100.00 & 100.00 & 100.00 & No difference & $\begin{array}{l}\text { Pearson's } \\
\text { Chi-squared }\end{array}$ \\
\hline Supports physical and cognitive condition & 41.18 & 57.43 & 61.54 & $4.74(p=0.093)$ & $\begin{array}{l}\text { Pearson's } \\
\text { Chi-squared }\end{array}$ \\
\hline $\begin{array}{l}\text { Types of support provided } \\
\text { Provides activity of daily living assistance }\end{array}$ & 56.86 & 41.58 & 33.33 & $5.47(p=0.065)$ & $\begin{array}{l}\text { Pearson's } \\
\text { Chi-squared }\end{array}$ \\
\hline $\begin{array}{l}\text { Provides instrumental activity of daily living } \\
\text { assistance }{ }^{\mathrm{b}} \\
\text { Responsibilities for communication with } \\
\text { healthcare providers }\end{array}$ & 100.00 & 99.01 & 100.00 & $0.90(p=0.639)$ & $\begin{array}{l}\text { Fisher's exact } \\
\text { test }\end{array}$ \\
\hline $\begin{array}{l}\text { Responsible for communicating with care recipient's } \\
\text { healthcare providers }\end{array}$ & 68.63 & 89.11 & 74.36 & $10.33(p=0.006)$ & $\begin{array}{l}\text { Pearson's } \\
\text { Chi-squared }\end{array}$ \\
\hline $\begin{array}{l}\text { Accessed care recipient's online medical } \\
\text { record in the past } 12 \text { months }\end{array}$ & 27.45 & 11.88 & 12.82 & $6.46(p=0.04)$ & $\begin{array}{l}\text { Pearson's } \\
\text { Chi-squared }\end{array}$ \\
\hline
\end{tabular}

${ }^{a}$ Activities of daily living include feeding, dressing, bathing, toileting, and movement in and out of bed

${ }^{b}$ Instrumental activities of daily living include shopping, transportation, and preparing meals

pandemic demonstrate the need for patients to access care providers without requiring in-person visits. The rapid expansion of innovations like telehealth, including access to patient portals, during the pandemic demonstrates that it is possible to increase use of these technologies. COVID-19 also reveals challenges, including disparities in access to these resources. ${ }^{5}$ We find that prior to the pandemic few family caregivers of adults were using online portals despite being responsible for communication. This is concerning and suggests a need for policies and practices to encourage and enable greater access by family caregivers. Providers should identify whether their patients have a family caregiver who should be involved in care discussions and could benefit from accessing the online medical record. They should discuss with patients and caregivers any concerns (e.g., about privacy and confidentiality) or preferences regarding access to the online medical record, as well as implications of caregiver record access. ${ }^{3}$ For instance, caregivers who are adult children may see inheritable risk factors when viewing the online record or may learn about a parent's medical history (e.g., stigmatized conditions) that the parent may want kept private. Alternatively, patients may want their caregiver to be aware of important decisions such as do not resuscitate preferences. As such, robust proxy access procedures as 
Table 2 Odds ratios of family caregiver characteristics to responsibility for communicating with providers and having accessed the online medical record, adjusting for demographic factors, and caregiving responsibilities

\begin{tabular}{|c|c|c|c|c|}
\hline & $\begin{array}{l}\text { Responsible for communicating } \\
\text { Odds ratio (OR) }\end{array}$ & $p$ Value & $\begin{array}{l}\text { Accessed online medical record } \\
\text { Odds ratio (OR) }\end{array}$ & $p$ Value \\
\hline \multicolumn{5}{|l|}{ Type of family care recipient } \\
\hline Spouse & Ref & Ref & Ref & Ref \\
\hline Parent & 4.34 & 0.003 & 0.28 & 0.011 \\
\hline Another family member & 1.23 & 0.701 & 0.32 & 0.067 \\
\hline \multicolumn{5}{|l|}{ Gender } \\
\hline Male & Ref & Ref & Ref & Ref \\
\hline Female & 2.01 & 0.098 & 1.82 & 0.200 \\
\hline \multicolumn{5}{|l|}{ Race/ethnicity } \\
\hline Hispanic and/or non-White & Ref & Ref & Ref & Ref \\
\hline White non-Hispanic & 2.37 & 0.033 & 0.55 & 0.171 \\
\hline \multicolumn{5}{|l|}{ Education } \\
\hline High school or less & Ref & Ref & Ref & Ref \\
\hline Some college & 1.57 & 0.481 & 1.77 & 0.441 \\
\hline BA or higher & 2.11 & 0.231 & 1.74 & 0.443 \\
\hline \multicolumn{5}{|l|}{ Provides ADL assistance } \\
\hline No & Ref & Ref & Ref & Ref \\
\hline Yes & 0.82 & 0.647 & 1.30 & 0.566 \\
\hline \multicolumn{5}{|l|}{ Supports cognitive condition } \\
\hline No & Ref & Ref & Ref & Ref \\
\hline Yes & 2.46 & 0.034 & 1.77 & 0.196 \\
\hline Hours spent caregiving per week & 1.01 & 0.057 & 1.0 & 0.591 \\
\hline $\begin{array}{l}\text { Responsible for communicating with } \\
\text { care recipient's healthcare providers }\end{array}$ & - & - & 1.12 & 0.832 \\
\hline
\end{tabular}

Italicized values represent $p<0.05$

well as discussions about privacy and confidentiality regarding online medical record access are critical among adult care recipients and their caregivers. ${ }^{3,6}$

Bradley Iott, $\mathrm{MPH}, \mathrm{MS}^{1,2}$

Minakshi Raj, $P h D^{3}$

Jodyn Platt, $\mathrm{PhD}{ }^{4}$

Denise Anthony, $\mathrm{Ph} \mathrm{D}^{1}$

${ }^{1}$ Department of Health Management and Policy, University of Michigan School of Public Health,

Ann Arbor, MI, USA

${ }^{2}$ School of Information, University of Michigan,

Ann Arbor, MI, USA

${ }^{3}$ Department of Kinesiology and Community Health, University of Illinois-Urbana Champaign,

Champaign, IL, USA

${ }^{4}$ Department of Learning Health Sciences, University of Michigan Medical School,

Ann Arbor, MI, USA

Corresponding Author: Bradley Iott, MPH, MS; School of Information, University of Michigan, Ann Arbor, MI, USA (e-mail: biott@umich.edu).

\section{Compliance with Ethical Standards:}

Conflicts of Interest: The authors declare that they have no conflict of interest.

\section{REFERENCES}

1. Wolff JL, Spillman BC, Freedman VA, Kasper JD. A National Profile of Family and Unpaid Caregivers Who Assist Older Adults With Health Care Activities. JAMA Intern Med. 2016;176(3):372-379. doi:https://doi.org/10. 1001/jamainternmed.2015.7664

2. Wolff JL, Darer JD, Larsen KL. Family Caregivers and Consumer Health Information Technology. J Gen Intern Med. 2016;31(1):117-121. doi:https://doi.org/10.1007/s11606-015-3494-0

3. Lindeman DA, Kim KK, Gladstone C, Apesoa-Varano EC. Technology and Caregiving: Emerging Interventions and Directions for Research. The Gerontologist. 2020;60(Supplement_1):S41-S49. doi:https://doi.org/10. 1093/geront/gnz178

4. Wolff JL, Kim VS, Mintz S, Stametz R, Griffin JM. An environmental scan of shared access to patient portals. J Am Med Inform Assoc. 2018;25(4):408412.

5. Cutrino A, Santamaria J. Research on Family Caregivers: Understanding Levels of Burden and How to Provide Assistance. Home Healthc Now. 2013;31(6):331. doi:https://doi.org/10.1097/NHH.0b013e3182932f84

6. Latulipe C, Mazumder SF, Wilson RKW, et al. Security and Privacy Risks Associated With Adult Patient Portal Accounts in US Hospitals. JAMA Intern Med. Published online May 4, 2020. doi:https://doi.org/10.1001/ jamainternmed.2020.0515

Publisher's Note: Springer Nature remains neutral with regard to jurisdictional claims in published maps and institutional affiliations. 